\title{
CLEARFIELD-viljelymenetelmä torjuu rypsin rikkakasvit tehokkaasti
}

\author{
Kati Lassi ${ }^{1}$ ja Pentti Ruuttunen ${ }^{2}$ \\ ${ }^{1)}$ Helsingin yliopisto, Maataloustieteiden laitos, PL 27, 00014 Helsingin yliopisto, \\ kati.lassi@helsinki.fi \\ ${ }^{2)}$ MTT Kasvintuotannon tutkimus, 31600 Jokioinen, pentti.ruuttunen@mtt.fi
}

\section{Tiivistelmä}

Rikkakasvien torjunta on yksi tärkeimmistä viljelytoimenpiteistä öljykasvien viljelyssä. Rikkakasvit alentavat satoa ja heikentävät sadon laatua ja siten myös sen arvoa. Suomessa rikkakasvien torjunta rypsi- ja rapsipelloilta on ollut ongelmallista vuosikymmenien ajan tehokkaiden herbisidien vähyyden ja valmisteiden korkeiden käyttökustannusten vuoksi. Käytetyin tehoaine, trifluraliini poistui markkinoilta kevään 2009 jälkeen, mikä tullee edelleen vähentämään herbisidien käyttöä, ellei uusia korvaavia valmisteita löydy.

CLEARFIELD-viljelymenetelmä tarjoaa toivottavasti pian myös Suomessa tehokkaan rikkakasvien torjuntakeinon rypsipelloille. BASF Ag:n kehittämässä CLEARFIELD-viljelymenetelmässä käytetään kasvilajiketta (tässä tapauksessa rypsiä), joka on jalostettu kestämään imidatsolinoniherbisidien (IMI-) ryhmään kuuluvaa herbisidiä. Kestävyys IMI-herbisideille on mahdollista jalostaa perinteisen kasvinjalostuksen menetelmin. Helsingin yliopiston soveltavan biologian laitoksella on tehty tutkimusta ja IMI-kestävyyden jalostustyötä suomalaisiin rypsi- ja rapsilinjoihin vuodesta 2002 lähtien.

Kasvukaudella 2009 järjestettiin saman koemallin mukaisesti viisi kenttäkoetta, joissa tutkittiin neljän taimettumisen jälkeen käytettävän herbisidin tehoa rypsipeltojemme 2-sirkkaisiin rikkakasvilajeihin. Kolme herbisideistä sisälsi ainoana tai toisena tehoaineenaan IMI-herbisidien ryhmään kuuluvaa imatsamoksia. Standardikäsittelynä kokeissa oli markkinoilla oleva Butisan S -valmiste, joka sisältää tehoaineenaan metatsakloria. Kenttäkokeet toteutettiin Helsingin yliopiston, BASF SE:n, MTT Jokioisten sekä Bernerin yhteistyönä. Herbidisidikokeiden lisäksi 14 rypsinviljelijää kokeili CLEARFIELD-viljelymenetelmää tiloillaan yhteensä lähes 130 ha:n alalla. Kaikissa kokeissa käytettiin kylvösiemenenä imatsamoksia kestävää 'IMI4003' kevätrypsilajiketta.

Herbisidikäsittelyt eivät aiheuttaneet rypsille vioituksia eikä niillä ollut muitakaan suoria vaikutuksia rypsin kasvuun. Imatsamoksiherbisideillä oli kaikissa kokeissa selvästi Butisan $\mathrm{S}$ standardikäsittelyä parempi teho rikkakasveihin. Imatsamoksiherbisidit tehosivat erittäin hyvin jauhosavikkaan, mataraan ja peltoukonnauriiseen. Hyvä teho valmisteilla oli pihatähtimöön, linnunkaaliin, kiertotattareen, peltopillikkeeseen ja peltohatikkaan ja kohtalainen teho punapeippiin, orvokkiin ja emäkkiin. Imatsamoksiherbisidien käytöstä saatiin myös viljelijäkokeissa erittäin hyviä tuloksia. Imatsamoksiherbisideillä havaittiin viljelijäkokeessa olevan tehoa myös juolavehnään, pelto-ohdakkeeseen ja hukkakauraan. CLEARFIELD-viljelymenetelmä soveltuu kasvukaudella 2009 kerättyjen kokemusten perusteella hyvin käytettäväksi Suomen olosuhteissa ja se tarjoaa tehokkaan tavan torjua rypsipeltojen yleisimmät ja haitallisimmat rikkakasvilajit.

Asiasanat: CLEARFIELD-viljelymenetelmä, rypsi, rikkakasvien torjunta, imidatsolinoni, herbisidikestävyys, imatsamoksi, metatsaklori 


\section{Johdanto}

Ongelmat rikkakasvien torjunnassa rypsillä ja rapsilla ovat Suomessa yksi niiden satotasoa alentavista tekijöistä (VYR 2008). Rypsillä ja rapsilla herbisidejä käytetään rikkakasvien torjuntaan erittäin vähän, herbisidien käyttöaste on arviolta 30-40 \% (VYR 2008). Pääsyynä herbisidien vähäiseen käyttöön on ollut tehokkaiden herbisidien puute ja toisaalta myös useiden herbisidivalmisteiden korkeat käyttökustannukset (VYR 2008). Käytetyimmät, trifluraliinia tehoaineena sisältäneet valmisteet poistuivat käytöstä kevään 2009 jälkeen oltuaan vuosia hyväksyttyinä poikkeusluvilla (Evira 2009). Näiden valmisteiden poistumisen ennustetaan entisestään vähentävän herbisidien käyttöä rikkakasvien torjuntaan (VYR 2008). Ongelmat rikkakasvien torjunnassa näkyvät suoraan sadon heikompana laatuna (MMM 2003).

CLEARFIELD-viljelymenetelmä tarjoaa toivottavasti pian myös Suomessa tehokkaan rikkakasvien torjuntamenetelmän rypsiviljelyksiltä. BASF Ag:n kehittämässä CLEARFIELD viljelymenetelmässä käytetään lajiketta (tässä tapauksessa rypsiä), joka on jalostettu kestämään imidatsolinoniherbisidien (IMI-) ryhmään kuuluvaa tehoainetta. Kestävyys IMI-herbisideille on mahdollista jalostaa perinteisen kasvinjalostuksen menetelmin (Tan ym. 2005). Kanadalaiset tutkijat onnistuivat mikrosporimutaatioita hyödyntäen jalostamaan IMI-kestävyyden kevätrapsiin 1980-luvun lopussa (Swanson ym. 1988, Swanson ym. 1989). Ensimmäinen CLEARFIELD-rapsilajike tuli Kanadassa markkinoille vuonna 1998 (McVetty \& Zelmer 2007). Vuonna 2007 Kanadassa viljellystä rapsista $11 \%$ oli CLEARFIELD-lajikkeita (Canada Grains Council 2008). Helsingin yliopiston soveltavan biologian laitoksella on tehty tutkimusta ja IMI-kestävyyden jalostustyötä suomalaisiin rypsi- ja rapsilinjoihin vuodesta 2002 lähtien. IMI-kestävyyden jalostuksessa suomalaisiin rypsi- ja rapsilinjoihin on hyödynnetty takaisinristeytysmenetelmää (Haukkapää ym. 2006).

Imidatsolinoni-herbisidien toiminta perustuu kasveissa kolmen haaroittuneen aminohapon muodostumista katalysoivan asetolaktataattisyntaasi-entsyymin (ALS) toiminnan estämiseen (Shaner ym. 1984). Suomessa tehdyissä kenttäkokeissa IMI-herbisidillä (tehoaine imatsamoksi) on todettu olevan hyvä teho mm. öljykasvipeltojen taloudellisesti haitallisimpiin rikkakasvilajeihin, jauhosavikkaan (Chenopodium album L.) ja peltomataraan (Galium spurium L.) (Haukkapää ym. 2005, Haukkapää ym. 2006). Kesällä 2009 järjestetyissä kenttäkokeissa haluttiin edelleen selvittää imatsamoksia sisältävien herbisidien tehoa suomalaiseen rikkakasvilajistoon ja niiden soveltuvuutta suomalaiselle IMIkestävälle rypsille.

\section{Aineisto ja menetelmät}

\section{Herbisidikokeet}

Kesällä 2009 järjestettiin saman koemallin mukaisesti viisi kenttäkoetta, joissa tutkittiin neljän taimettumisen jälkeen käytettävän herbisidin tehoa rypsipeltojemme 2-sirkkaisiin rikkakasvilajeihin (Taulukko 1). Kolme herbisideistä (BAS79700H, BAS79701H ja BAS72006H) sisälsi ainoana tai toisena tehoaineenaan IMI-herbisidien ryhmään kuuluvaa imatsamoksia. Standardikäsittelynä kokeissa oli markkinoilla oleva Butisan S herbisidi, joka sisältää tehoaineenaan metatsakloria. Kenttäkokeet toteutettiin Helsingin yliopiston, BASF:n, MTT Jokioisten sekä Bernerin yhteistyönä.

Koepaikat sijaitsivat Helsingissä (Viikki), Forssassa (2 koetta) sekä Somerolla ja Tammelassa. Koemallina kokeissa oli satunnaistettujen lohkojen muotoinen koe. Kokeissa käytettiin kylvösiemenenä 'IMI4003' kevätrypsilajiketta, joka on jalostettu Helsingin yliopiston soveltavan biologian laitoksella. Kylvösiemenmäärät vaihtelivat koepaikasta riippuen $250-330 \mathrm{kpl} / \mathrm{m}^{2}$ välillä, mikä vastaa $7,3-$ 7,8 kg/ha kylvösiemenmääriä. Koeruutujen koot vaihtelivat koepaikoittain, Viikissä koeruutu oli kooltaan $11,6 \mathrm{~m}^{2}$, Forssassa $24 \mathrm{~m}^{2}$ ja Somerolla ja Tammelassa $30 \mathrm{~m}^{2}$. Kaikissa kokeissa oli neljä kerrannetta.

Herbisidikäsittelyt tehtiin kesäkuun alussa rypsin ollessa 2-4 lehti-asteella työnnettävällä tai kannettavalla kasvinsuojeluruiskulla. Kaikilta koepaikoilta tehtiin tavanomaiset kasvuhavainnot, joiden lisäksi tehtiin vioitushavainnot 7 ja 14 päivää herbisidikäsittelyjen jälkeen. Rikkakasvilaskennat tehtiin 25-30 päivää herbisidikäsittelyn jälkeen. Jokaisesta ruudusta kerättiin $1 \mathrm{~m}^{2}: \mathrm{n}$ alalta (Viikissä $0,5 \mathrm{~m}^{2}$ ) kaikki rikkakasvit, jotka lajiteltiin ja niiden kappalemäärät laskettiin. Rikkakasvinäytteet kui- 
vattiin ja niiden kuivapainot punnittiin tämän jälkeen. Puinnin jälkeen määritettiin rypsin sato $(\mathrm{kg} / \mathrm{ha})$, sadon öljy-, valkuais- ja klorofyllipitoisuus (NIR), puhtaus ja 1000 siemenen paino. Tulosten tilastollinen analysointi tehtiin MTT:ssa Agriculture Research Manager 7.5.0 - ohjelmistolla (Gylling Data Management, USA).

Taulukko 1. Kenttäkokeissa käytetyt herbisidit ja niiden käyttömäärät ja tehoaineet (g/ha). DASHvalmiste on kiinnite jota käytettiin BAS79700H ja BAS79701H valmisteiden kanssa.

\begin{tabular}{|c|c|c|}
\hline $\begin{array}{l}\text { Koejäsenen } \\
\text { numero }\end{array}$ & $\begin{array}{l}\text { Käytetty herbisidivalmiste ja valmisteen käyttö- } \\
\text { mä̈̈rä }(l / h a)\end{array}$ & Tehoaineiden määrä eri koejäsenissä $(g / h a)$ \\
\hline 1 & Käsittelemätön & \\
\hline 2 & BAS79701H 1,0 1/ha + DASH 1,0 1/ha & imatsamoksi $25 \mathrm{~g}+$ metatsaklori $375 \mathrm{~g}$ \\
\hline 3 & BAS79701H 1,5 1/ha + DASH 1,0 1/ha & imatsamoksi 37,5 g + metatsaklori $563 \mathrm{~g}$ \\
\hline 4 & BAS79701H 3,0 1/ha + DASH 1,0 1/ha & imatsamoksi $75 \mathrm{~g}+$ metatsaklori $1125 \mathrm{~g}$ \\
\hline 5 & BAS79701H 1,5 l/ha & imatsamoksi 37,5 g + metatsaklori $563 \mathrm{~g}$ \\
\hline 6 & BAS79700H 1,0 1/ha + DASH 1,0 1/ha & imatsamoksi 17,5 g + metatsaklori $375 \mathrm{~g}$ \\
\hline 7 & BAS79700H 1,5 1/ha + DASH 1,0 1/ha & imatsamoksi 26,3 g + metatsaklori $563 \mathrm{~g}$ \\
\hline 8 & BAS79700H 2,0 1/ha + DASH 1,0 1/ha & imatsamoksi $35 \mathrm{~g}$ + metatsaklori $750 \mathrm{~g}$ \\
\hline 9 & BAS72006H 1,0 1/ha & imatsamoksi $40 \mathrm{~g}$ \\
\hline 10 & BAS72006H 2,0 l/ha & imatsamoksi $80 \mathrm{~g}$ \\
\hline 11 & Butisan S 3,0 l/ha & metatsaklori $1500 \mathrm{~g}$ \\
\hline
\end{tabular}

\section{Viljelijäkokeet}

Edellä mainittujen herbidisidikokeiden lisäksi 14 viljelijää kokeili CLEARFIELD-viljelymenetelmää yhteensä 128 ha:n alalla. Viljelijöille toimitettiin keväällä kylvösiemenet (rypsilajike IMI4003) ja imatsamoksia sisältävä herbisidi (BAS79700H 1,5 1/ha + DASH-kiinnite tai BAS72006H 1,0 1/ha). Viljelijät tekivät kasvukaudella kaikki viljelytoimenpiteet itse kylvöstä sadonkorjuuseen haluamallaan tavalla. Herbisidikäsittely tehtiin annettujen ohjeiden mukaisesti tavallisella kasvinsuojeluruiskulla rypsikasvustojen ollessa 3-4 lehtiasteella. Jokainen viljelijä jätti käsittelemättömän kaistan peltoonsa, jotta herbsidien tehoa oli mahdollista arvioida. Suurin osa viljelijäkokeeseen osallistuneiden viljelijöiden tiloista sijaitsi Etelä- ja Lounais-Suomessa ja pohjoisimmat tilat Isossakyrössä. Viljelijöiden viljelymuistiinpanot ja käyttäjäkokemuksia kerättiin kasvukauden jälkeen keväällä toimitetulla lohkotietolomakkeella.

\section{Tulokset ja tulosten tarkastelu}

\section{Kasvuhavainnot}

Herbisidikäsittelyt eivät aiheuttaneet rypsille vioituksia Viikin, Someron ja Tammelan koepaikoilla. Forssan molemmilla koepaikoilla havaittiin erittäin lieviä vioituksia, jotka olivat ohimeneviä. Herbisidikäsittelyillä ei ollut vaikutusta rypsikasvuston pituuteen, kukinnan alkamiseen, kukinnan kestoon tai kasvuaikaan millään koepaikalla. Rypsikasvustot lakoutuivat vihreälituvaiheessa jonkin verran koepaikasta riippuen. Herbisidikäsittelyillä ei ollut vaikutusta kasvuston lakoutumiseen.

\section{Rikkakasvilaskentojen tulokset}

Rikkakasvien lukumäärä ja rikkakasvilajisto vaihtelivat suuresti koepaikoittain. Erittäin paljon rikkakasveja taimettui Forssan hietamoreenimaan kokeella. Käsittelemättömän koejäsenen ruuduissa oli keskimäärin 371 2-sirkkaista, yksivuotista rikkakasvia/m $\mathrm{m}^{2}$ ja niiden kuivapaino oli $48,9 \mathrm{~g} / \mathrm{m}^{2}$ (Taulukko 2). Yleisimmät rikkakasvilajit olivat jauhosavikka, kiertotatar (Fallopia convolvulus L.), peltopillike (Galeopsis ssp.), peltohatikkka (Spergula arvensis L.) ja peltoukonnauris (Erysimum 
cheiranthoides L.). Viikissä ja Forssan multamaan kokeella rikkakasveja taimettui kohtalaisesti. Viikissä käsittelemättömän koejäsenen ruuduissa oli keskimäärin 85 2-sirkkaista, yksivuotista rikkakas$\mathrm{via} / \mathrm{m}^{2}$ ja niiden kuivapaino oli $0,89 \mathrm{~g} / \mathrm{m}^{2}$. Forssan multamaan kokeella käsittelemättömän koejäsenen ruuduissa oli keskimäärin 72 2-sirkkaista, yksivuotista rikkakasvia/ $\mathrm{m}^{2}$ ja niiden kuivapaino oli keskimäärin $5,5 \mathrm{~g} / \mathrm{m}^{2}$. Viikissä yleisimmät rikkakasvilajit olivat punapeippi (Lamium purpureum L.), peltoorvokki (Viola arvensis L.), emäkki (Fumaria officinalis L.), jauhosavikka ja peltoukonnauris ja Forssan multamaalla linnunkaali (Lapsana communis L.), matara, pihatähtimö (Stellaria media L.) ja peltoukonnauris. Vähiten rikkakasveja taimettui Someron ja Tammelan koepaikoilla. Someron kokeella käsittelemättömän koejäsenen ruuduilla taimettui keskimäärin 42 2-sirkkaista, yksivuotista rikkakas$\mathrm{via} / \mathrm{m}^{2}$ ja niiden kuivapaino oli $14,5 \mathrm{~g} / \mathrm{m}^{2}$. Yleisimmät rikkakasvilajit olivat kokeella punapeippi, jauhosavikka, pelto-orvokki ja matara. Tammelassa käsittelemättömän koejäsenen ruuduilla oli keskimäärin 27 2-sirkkaista, yksivuotista rikkakasvia/ $/ \mathrm{m}^{2}$ ja niiden kuivapaino oli keskimäärin $3,1 \mathrm{~g} / \mathrm{m}^{2}$. Yleisimmät rikkakasvilajit kokeella olivat matara, pihatähtimö ja jauhosavikka.

Taulukko 2. 2-sirkkaisten, yksivuotisten rikkakasvien lukumäärä $\left(\mathrm{kpl} / \mathrm{m}^{2}\right)$ ja kuivapaino $\left(\mathrm{g} / \mathrm{m}^{2}\right)$ viidellä eri koepaikalla. Eri kirjaimin merkityt sarakkeen luvut eroavat tilastollisesti toisistaan ( $p<0,05$, Student-Newman-Keuls). Rikkakasvien biomassatulosten tilastollinen analysointi Forssan, Someron ja Tammelan koepaikoilta ei ollut mahdollista, koska aineisto ei muunnostenkaan jälkeen ollut normaalijakautunut.

\begin{tabular}{|c|c|c|c|c|c|c|c|c|c|c|}
\hline & \multicolumn{2}{|c|}{ Forssa HtMr } & \multicolumn{2}{|c|}{ Forssa rmHtS } & \multicolumn{2}{|c|}{ Viikki } & \multicolumn{2}{|c|}{ Somero } & \multicolumn{2}{|c|}{ Tammela } \\
\hline & $\mathrm{kpl} / \mathrm{m} 2$ & $\mathrm{~g} / \mathrm{m} 2$ & $\mathrm{kpl} / \mathrm{m} 2$ & $\mathrm{~g} / \mathrm{m} 2$ & $\mathrm{kpl} / \mathrm{m} 2$ & $\mathrm{~g} / \mathrm{m} 2$ & $\mathrm{kpl} / \mathrm{m} 2$ & $\mathrm{~g} / \mathrm{m} 2$ & $\mathrm{kpl} / \mathrm{m} 2$ & $\mathrm{~g} / \mathrm{m} 2$ \\
\hline Käsittelemätön & $371 \mathrm{a}$ & $48,9 \mathrm{a}$ & $72 \mathrm{a}$ & 5,5 & $85 \mathrm{a}$ & $7,4 \mathrm{a}$ & $42 \mathrm{a}$ & 14,5 & $27 \mathrm{a}$ & 3,1 \\
\hline BAS79701H 1,0 1/ha + DASH & 37 cde & $1,2 \mathrm{ef}$ & $20 \mathrm{bc}$ & 0,4 & $38 \mathrm{a}$ & $1,1 \mathrm{~b}$ & $20 \mathrm{abc}$ & 0,6 & $7 \mathrm{a}$ & 0,2 \\
\hline BAS79701H 1,5 1/ha + DASH & $52 \mathrm{~b}-\mathrm{e}$ & $1,2 \mathrm{e}$ & $7 \mathrm{~cd}$ & 0,1 & $43 \mathrm{a}$ & $1,5 \mathrm{~b}$ & $3 \mathrm{c}$ & 0,1 & $4 \mathrm{a}$ & 0,1 \\
\hline BAS79701H 3,0 1/ha + DASH & $7 \mathrm{f}$ & $0,2 \mathrm{f}$ & $2 d$ & 0,1 & $40 \mathrm{a}$ & $1,2 \mathrm{~b}$ & $8 \mathrm{bc}$ & 0,2 & $2 \mathrm{a}$ & 0 \\
\hline BAS79701H 1,5 1/ha & $86 \mathrm{bc}$ & $3,5 \mathrm{c}$ & $19 \mathrm{bc}$ & 0,3 & $62 \mathrm{a}$ & $2,3 \mathrm{~b}$ & $41 \mathrm{a}$ & 2,4 & $14 \mathrm{a}$ & 0,7 \\
\hline BAS79700H 1,0 1/ha + DASH & $58 \mathrm{bcd}$ & $1,6 \mathrm{de}$ & $12 \mathrm{bcd}$ & 0,2 & $61 \mathrm{a}$ & $1,7 \mathrm{~b}$ & $14 \mathrm{abc}$ & 0,5 & $5 \mathrm{a}$ & 0,1 \\
\hline BAS79700H 1,5 1/ha + DASH & $42 \mathrm{~b}-\mathrm{e}$ & 0,9 ef & $15 \mathrm{bcd}$ & 0,2 & $49 \mathrm{a}$ & $1,6 \mathrm{~b}$ & $8 \mathrm{bc}$ & 0,3 & $7 \mathrm{a}$ & 0,7 \\
\hline BAS79700H 2,0 1/ha + DASH & 16 ef & 0,5 ef & $8 \mathrm{bcd}$ & 0,1 & $27 \mathrm{a}$ & $0,8 \mathrm{~b}$ & $17 \mathrm{abc}$ & 0,5 & $7 \mathrm{a}$ & 0,1 \\
\hline BAS72006H 1,0 1/ha & $97 \mathrm{~b}$ & $2,9 \mathrm{~cd}$ & $11 \mathrm{bcd}$ & 0,2 & $50 \mathrm{a}$ & $2 b$ & $28 \mathrm{ab}$ & 1,3 & $4 \mathrm{a}$ & 0,1 \\
\hline BAS72006H 2,0 1/ha & 30 def & 0,9 ef & $12 \mathrm{bcd}$ & 0,3 & $40 \mathrm{a}$ & $1,5 \mathrm{~b}$ & $17 \mathrm{abc}$ & 0,8 & $4 \mathrm{a}$ & 0,2 \\
\hline Butisan S 3,0 1/ha & $298 \mathrm{a}$ & $15,7 \mathrm{~b}$ & $27 \mathrm{~b}$ & 1,3 & $66 \mathrm{a}$ & $5,7 \mathrm{a}$ & $28 \mathrm{ab}$ & 9 & $9 \mathrm{a}$ & 0,3 \\
\hline
\end{tabular}

Kokeessa mukana olleilla kolmella imatsamoksia toisena tai ainoana tehoaineena sisältävällä herbisidivalmisteella oli kaikissa kokeissa hyvä tai erittäin hyvä teho koepaikoilla esiintyneeseen rikkakasvilajistoon (Kuva 1 ja kuva 2). Butisan S -standardikäsittelyn teho oli sen sijaan useassa kokeessa vain kohtalainen. Imatsamoksiherbisidit vähensivät kaikissa kokeissa rikkakasvien biomassaa 70-100 \% käsittelemättömään koejäseneen verrattuna. Forssan molemmilla koepaikoilla herbisidikäsittelyt vähensivät rikkakasvien biomassa yli 93 \% käsittelemättömään koejäseneen verrattuna. Useilla koepaikoilla valmisteen käyttömäärän kasvattaminen lisäsi sen tehoa rikkakasveihin. DASH - kiinnitteen havaittiin useassa kokeessa lisäävän BAS79701H valmisteen tehoa.

Rikkakasvilaskentojen tulosten perusteella imatsamoksiherbisideillä oli erittäin hyvä teho jauhosavikkaan, mataraan ja peltoukonnauriiseen. Myös aiemmissa, Suomessa tehdyissä kokeissa imatsamoksia sisältävien herbisidien tehon jauhosavikkaan ja mataraan on todettu olevan erittäin hyvä (Haukkapää ym. 2005, Ruuttunen 2009). Hyvä teho imatsamoksiherbisideillä oli pihatähtimöön, linnunkaaliin, kiertotattareen, peltopillikkeeseen ja peltohatikkaan. Kohtalainen teho valmisteilla oli peippiin, orvokkiin ja emäkkiin. Imatsamoksia sisältävän herbisidin teho peippiin, orvokkiin ja emäkkiin on todettu heikoksi aiemmissa tutkimuksissa (Haukkapää ym. 2005).

Imatsamoksiherbisidien vaikutus rikkakasveihin havaitaan usein viikon tai vasta kahden viikon päästä käsittelystä. Näissä kokeissa herbisidikäsittelyn vaikutukset näkyivät rikkakasvilajeista ensimmäiseksi jauhosavikassa, jonka taimet "kaatuivat" reilun viikon päästä käsittelystä. Imatsamoksiher- 
bisidit eivät tapa kaikkia rikkakasvilajeja, mutta niiden kasvu tyrehtyy ja ne eivät usein tuota siemeniä. Tämä havainto tehtiin myös kesän 2009 kaikilla koepaikoilla. Esimerkiksi Viikin koepaikalla, jossa yleisimpinä rikkakasvilajeina olivat punapeippi ja orvokki, herbisidikäsittelyt eivät vähentäneet rikkakasvien lukumääriä paljoa, mutta rikkakasvien biomassa väheni kuitenkin tilastollisesti merkitsevästi $(\mathrm{p}<0,05)$ käsittelemättömään koejäseneen verrattuna.

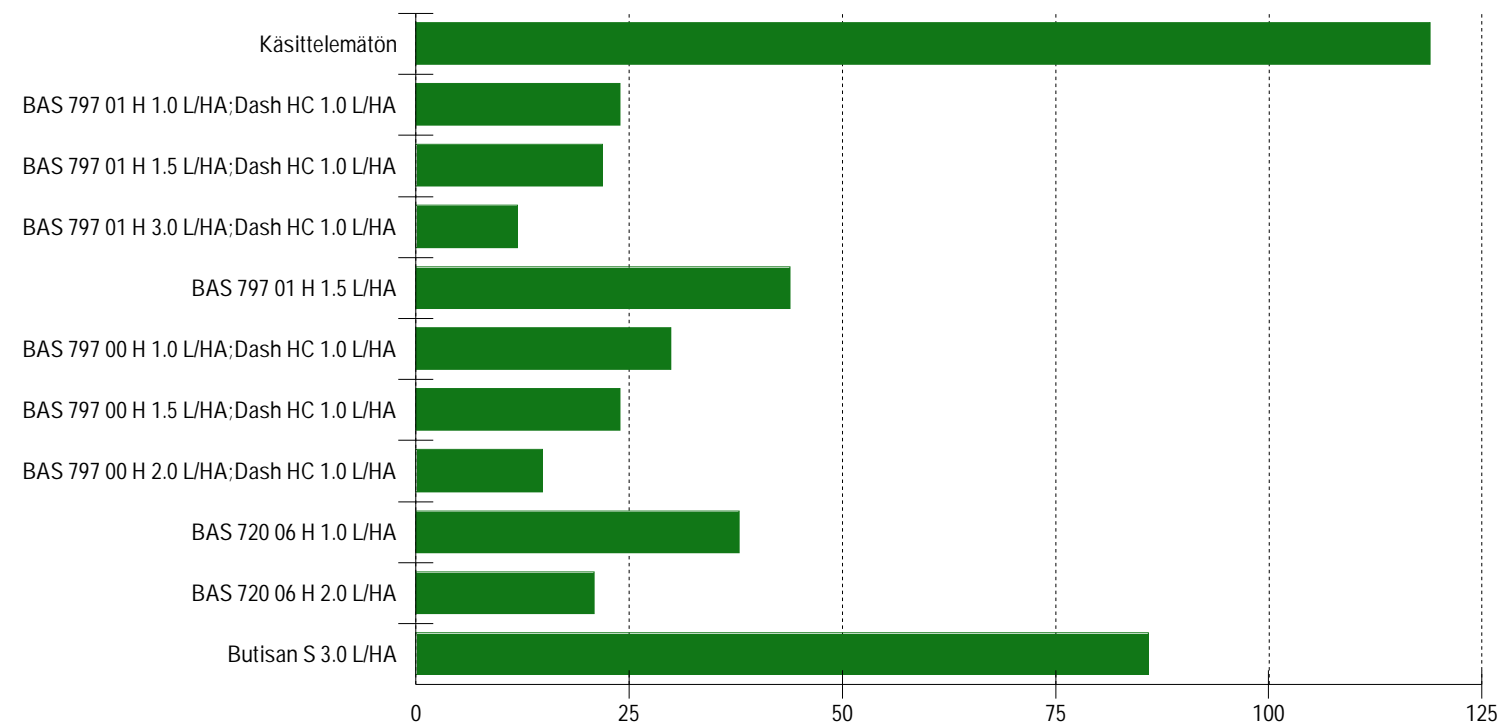

Kuva 1. 2-sirkkaisten, yksivuotisten rikkakasvien lukumäärä $\left(\mathrm{kpl} / \mathrm{m}^{2}\right) 25-30$ päivää herbisidikäsittelystä kesällä 2009 järjestettyjen viiden kokeen keskiarvoina.

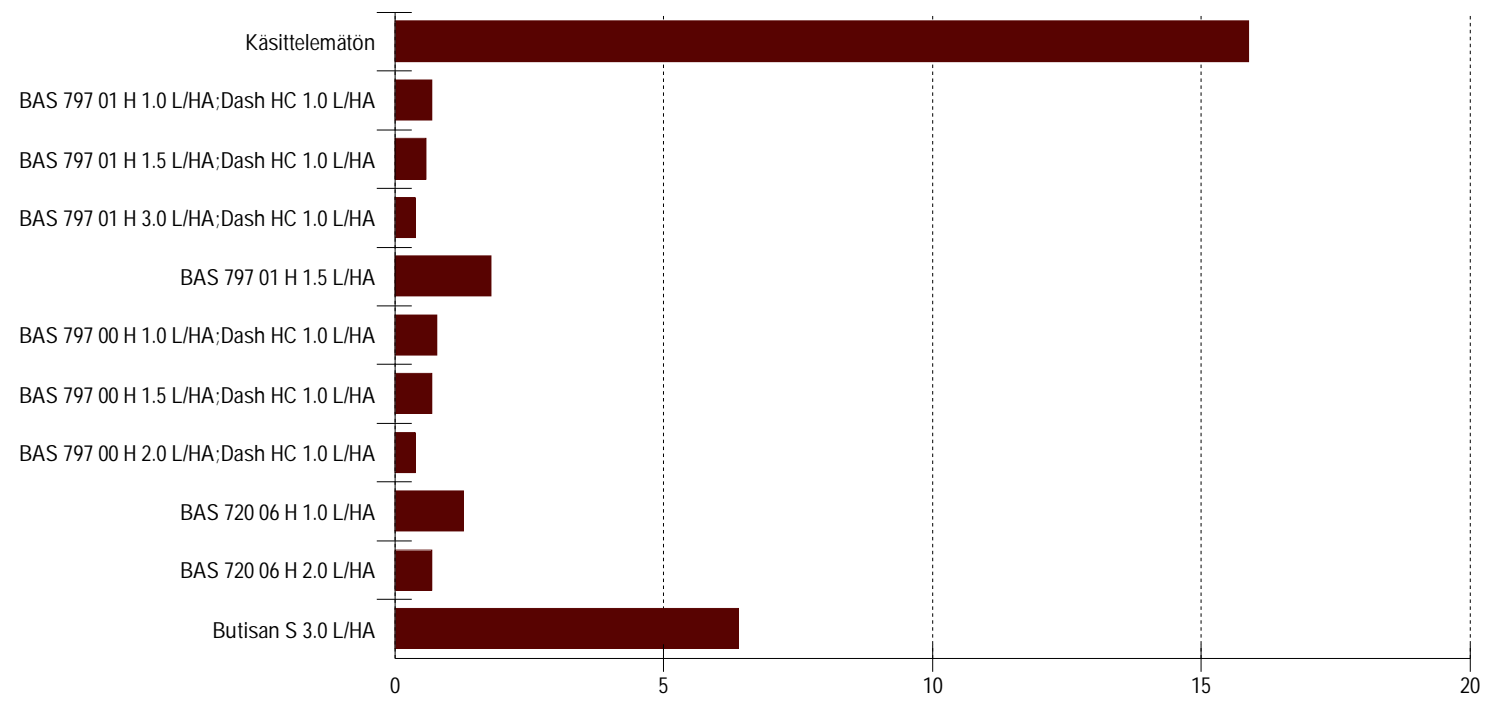

Kuva 2. 2-sirkkaisten, yksivuotisten rikkakasvien kuivapaino $\left(\mathrm{g} / \mathrm{m}^{2}\right) 25-30$ päivää herbisidikäsittelystä kesällä 2009 järjestettyjen viiden kokeen keskiarvoina.

\section{Satotulokset}

Rypsin satotaso vaihteli koepaikoittain. Satotaso oli alhaisin Tammelan kokeella, $1600 \mathrm{~kg} / \mathrm{ha}$ ja korkein Viikin kokeella, $3500 \mathrm{~kg} / \mathrm{ha}$ (Taulukko 3). Tammelan kokeella esiintyi jonkin verran pahkahometta, mikä lienee syynä alhaisempiin ja osin myös epätasaisiin ruutusatoihin. Rikkakasvien torjunta herbisideillä kasvatti Forssan hietamoreenimaalla rypsin satoa käsittelemättömään koejäseneen verrattuna 15-24\% (p < 0,05). Muilla koepaikoilla herbisidikäsittelyt kasvattivat satoa hieman, mutta sadonlisät eivät olleet tilastollisesti merkitseviä $(p>0,05)$. Forssan hietamoreenimaan kokeella herbisidikäsittelyillä oli vaikutusta myös sadon puhtauteen ja erot käsittelemättömään koejäseneen ja 
standardikäsittelyyn olivat tilastollisesti merkitseviä $(\mathrm{p}<0,05)$. Forssan hietamoreenimaalla käsittelemättömän koejäsenen sadon puhtaus oli 94,7 \%, standardikäsittelyllä 97,1 \% ja herbisidikäsittelyissä yli $99,1 \%$. Mikäli sadon puhtaus on alle $98 \%$, tekevät öljynpuristamot sadosta maksettavaan hintaan laatuvähennyksiä. Herbisidikäsittelyt lisäsivät sadon puhtautta myös Forssan multamaan ja Viikin koepaikoilla hieman verrattuna käsittelemättömään koejäseneen, mutta erot eivät olleet tilastollisesti merkitseviä $(\mathrm{p}>0,05)$. Herbisidikäsittelyillä ei ollut millään koepaikoista negatiivista vaikutusta satoon.

Taulukko 3. Ruutusadot (kg/ha) ja sadon puhtaudet koepaikoittain. Sato on ilmoitettu $9 \%$ :n kosteudessa. Eri kirjaimet merkityt sarakkeen luvut eroavat tilastollisesti toisistaan ( $\mathrm{p}<0,05$, StudentNewman-Keuls). Someron ja Tammelan koepaikoilta ei sadon puhtautta määritetty.

\begin{tabular}{|l|c|c|c|c|c|c|c|c|}
\hline & \multicolumn{2}{|c|}{ Forssa HtMr } & \multicolumn{2}{c|}{ Forssa rmHtS } & \multicolumn{2}{|c|}{ Viikki } & Somero & Tammela \\
\cline { 2 - 8 } & $\mathrm{kg} / \mathrm{ha}$ & Puhtaus \% & $\mathrm{kg} / \mathrm{ha}$ & Puhtaus $\%$ & $\mathrm{~kg} / \mathrm{ha}$ & Puhtaus $\%$ & $\mathrm{~kg} / \mathrm{ha}$ & $\mathrm{kg} / \mathrm{ha}$ \\
\hline Käsittelemätön & $1791 \mathrm{~b}$ & $94,7 \mathrm{c}$ & $2395 \mathrm{a}$ & $98,3 \mathrm{a}$ & $3619 \mathrm{a}$ & 98,6 & $2321 \mathrm{a}$ & $1665 \mathrm{a}$ \\
BAS79701H 1,0 1/ha + DASH & $2095 \mathrm{a}$ & $99,3 \mathrm{a}$ & $2576 \mathrm{a}$ & $99,0 \mathrm{a}$ & $3551 \mathrm{a}$ & 99,5 & $2511 \mathrm{a}$ & $1742 \mathrm{a}$ \\
BAS79701H 1,5 1/ha + DASH & $2179 \mathrm{a}$ & $99,2 \mathrm{a}$ & $2475 \mathrm{a}$ & $98,7 \mathrm{a}$ & $3654 \mathrm{a}$ & 99,6 & $2407 \mathrm{a}$ & $1513 \mathrm{a}$ \\
BAS79701H 3,0 1/ha + DASH & $2228 \mathrm{a}$ & $99,3 \mathrm{a}$ & $2555 \mathrm{a}$ & $99,1 \mathrm{a}$ & $3592 \mathrm{a}$ & 99,6 & $2420 \mathrm{a}$ & $1530 \mathrm{a}$ \\
BAS79701H 1,5 1/ha & $2191 \mathrm{a}$ & $99,1 \mathrm{a}$ & $2605 \mathrm{a}$ & $98,5 \mathrm{a}$ & $3498 \mathrm{a}$ & 99,5 & $2440 \mathrm{a}$ & $1556 \mathrm{a}$ \\
BAS79700H 1,0 1/ha + DASH & $2168 \mathrm{a}$ & $99,3 \mathrm{a}$ & $2634 \mathrm{a}$ & $99,0 \mathrm{a}$ & $3725 \mathrm{a}$ & 99,7 & $2438 \mathrm{a}$ & $1643 \mathrm{a}$ \\
BAS79700H 1,5 1/ha + DASH & $2211 \mathrm{a}$ & $99,2 \mathrm{a}$ & $2619 \mathrm{a}$ & $98,4 \mathrm{a}$ & $3502 \mathrm{a}$ & 99,6 & $2463 \mathrm{a}$ & $1616 \mathrm{a}$ \\
BAS79700H 2,0 1/ha + DASH & $2168 \mathrm{a}$ & $99,3 \mathrm{a}$ & $2561 \mathrm{a}$ & $98,5 \mathrm{a}$ & $3589 \mathrm{a}$ & 99,7 & $2474 \mathrm{a}$ & $1674 \mathrm{a}$ \\
BAS72006H 1,0 1/ha & $2174 \mathrm{a}$ & $99,3 \mathrm{a}$ & $2532 \mathrm{a}$ & $98,8 \mathrm{a}$ & $4007 \mathrm{a}$ & 99,7 & $2514 \mathrm{a}$ & $1587 \mathrm{a}$ \\
BAS72006H 2,0 1/ha & $2122 \mathrm{a}$ & $99,1 \mathrm{a}$ & $2657 \mathrm{a}$ & $98,8 \mathrm{a}$ & $3523 \mathrm{a}$ & 99,6 & $2390 \mathrm{a}$ & $1744 \mathrm{a}$ \\
Butisan S 3,0 1/ha & $2058 \mathrm{a}$ & $97,1 \mathrm{~b}$ & $2503 \mathrm{a}$ & $98,9 \mathrm{a}$ & $3444 \mathrm{a}$ & 99,1 & $2246 \mathrm{a}$ & $1748 \mathrm{a}$ \\
\hline
\end{tabular}

\section{Viljelijäkokeet}

Viljelijäkokeet onnistuivat hyvin. Viljelymenetelmäkokeiluun osallistuneet viljelijät kylvivät rypsin toukokuun alun ja toukokuun lopun välisenä aikana, suurin osa kylvöistä tehtiin toukokuun puolen välin jälkeen. Viljelijät käyttivät kylvösiemenmääränä keskimäärin 7-8 kg/ha. Valtaosa viljelijöistä antoi lannoituksen kylvön yhteydessä, typpeä viljelykasville annettiin keskimäärin 90-120 kg N/ha. Kirppoja ja rapsikuoriaisia viljelijät torjuivat kasvukaudella vähintään kerran torjuntaruiskutuksilla. Kylmä sääjakso hidasti alkukasvukaudella hieman kasvustojen kehitystä ja ensimmäiset herbisidikäsittelyt tehtiin kesäkuun toisella viikolla ja viimeiset kesäkuun lopussa. Rypsi oli käsittelyhetkellä 3-4 lehti-asteella. Osa viljelijöistä teki täyskukinnan aikaan ruiskutuksen pahkahometta vastaan. Rypsikasvusto puitiin ensimmäisellä koepaikalla syyskuun alussa ja viimeiset puinnit tehtiin syyskuun lopulla. Viljelijät saivat hyviä rypsisatoja, kokeiluun osallistuneilla rypsin keskisato oli noin $2000 \mathrm{~kg} / \mathrm{ha}$.

Herbisidikäsittelyiden ei havaittu aiheuttavan vioituksia ja niillä ei ollut vaikutusta kukinnan alkamiseen, kukinnan kestoon, kasvuston pituuteen tai kasvuston kasvuaikaan. Viljelijät tekivät havainnot vertailemalla kasvustossa olleita käsittelemätöntä ja käsiteltyä kaistaa. Rikkakasvien esiintymisessä käsittelemättömän kaistan ja käsitellyn välillä sen sijaan oli selvästi havaittava ero. Samat havainnot tehtiin tiloilla vieraillessa. Viljelijät olivat tyytyväisiä molempien herbisidien tehoihin eikä herbisidien käyttöä koettu hankalaksi. Useat viljelijät kuvasivat herbisidien tehoa rikkakasveihin erittäin hyväksi. Erittäin hyvä teho valmisteilla oli mm. jauhosavikkaan. Viljelijöiden pelloilla havaittiin, että herbisideillä oli tehoa myös pelto-ohdakkeeseen, juolavehnään ja hukkakauraan. Näitä rikkakasvilajeja herbisidikäsittely ei kokonaan tapa, mutta rikkakasvien kasvu tyrehtyy ja ne jäävät kasvuston alle. 


\section{Johtopäätökset}

Kasvukaudella 2009 tehtyjen kenttä- ja viljelijäkokeiden perusteella imatsamoksiherbisideillä on hyvä ja laaja-alainen teho öljykasvipeltojemme yleisimpiin rikkakasvilajeihin. Erityisen merkittävää on, että imatsamoksiherbisidit tehoavat erinomaisesti rypsin taloudellisesti haitallisimpiin lajeihin jauhosavikkaan ja peltomataraan. Imatsamoksi tehoaa erinomaisesti myös ristikukkaisiin rikkakasveihin (mm. peltoukonnauris, peltotaskuruoho, lutukka), joihin rypsin muilla herbisideillä on tuskin lainkaan tehoa. Viitteet imatsamoksin tehosta pelto-ohdakkeeseen, hukkakauraan ja jopa juolavehnään ovat myös lupaavia. Koska imatsamoksi tehoaa rikkakasveihin pääosin lehtien kautta, sen käytön ajoitus ei ole yhtä tarkka eikä maalaji tai maan kosteus vaikuta sen tehoon yhtä paljon kuin maavaikutteisilla herbisideillä. Imatsamoksiherbisidien käyttö ajoittuu rypsin 2-5 lehtiasteelle ja siihen voidaan yhdistää tuholaisten torjuntakäsittely. Herbisidikäsittelyn ei havaittu aiheuttavan vioituksia IMI4003 kevätrypsilajikkeelle. Kokeella, jolla rikkakasveja esiintyi runsaimmin, imatsamoksiherbisidit lisäsivät selvästi sadon määrää ja myös sadon puhtautta, jolla on rypsillä taloudellista merkitystä. Kasvukaudella 2009 kerättyjen kokemusten perusteella CLEARFIELD-viljelymenetelmä rypsillä soveltuu hyvin käytettäväksi Suomen olosuhteissa. CLEARFIELD-viljelymenetelmä tarjoaa toivottavasti tulevina vuosina myös Suomessa tehokkaan tavan torjua rikkakasvit rypsipelloilta.

\section{Kirjallisuus}

Canada Grain Council. 2008. Creating an Environment for the SuccessfulCommercialization of Canadian Crop Innovation: Outcomes of a Collaborative Review by the Canada Grains Council and Industry Stakeholders. Verkkojulkaisu saatavilla: http://www.whybiotech.ca/resources/ca_crop_innovation_report.pdf

Elintarviketurvallisuusvirasto Evira. 2009. Kasvintuotanto ja rehut, kasvinsuojeluaineet, ajankohtaista. Uusia valmisteita ja käyttökohteiden muutoksia vuonna 2009. Verkkojulkaisu saatavilla:

http://www.evira.fi/portal/fi/kasvintuotanto_ja_rehut/kasvinsuojeluaineet/ajankohtaista/

Haukkapää, A-L., Junnila, S., Eriksson, C., Tulisalo, U. \& Seppänen, M. 2005. Efficacy of imazamox in imidazolinone-resistant spring oilseed rape in Finland. Agricultural and Food Science 14: 377-388.

Haukkapää, A-L, Seppänen, M. \&Tulisalo, U. 2006. Imidatsolinonit - vaihtoehto rypsin ja rapsin rikkakasvien torjuntaan. Teoksessa: Anneli Hopponen (toim.) Maataloustieteen Päivät 2006. Suomen maataloustieteellisen seuran julkaisuja no 21. Verkkojulkaisu saatavilla: http://www.smts.fi/esit06/0708.pdf

Maa- ja metsätalousministeriö, MMM. 2003. Öljykasvistrategia. Työryhmämuistio 2003:8. 53 s. Verkkojulkaisu saatavilla: http://wwwb.mmm.fi/julkaisut/tyoryhmamuistiot/2003/tr2003_8.pdf

McVetty, P.B.E. \& Zelmer, C.D. 2007. Breeding Herbicide-Tolerant Oilseed Rape Cultivars. Advances in Botanical Research 45: 233-270.

Ruuttunen, P. 2009. Evaluation of imazamox in spring turnip rape, Jokioinen. MTT Agrifood Research Finland, herbicides, trial report 2008. Verkkojulkaisu saatavilla:

https://portal.mtt.fi/portal/page/portal/mtt_en/mtt/facilities/testing_PPs/trialresults/2008/herbicides/08herb08.pdf Shaner, D.L., Anderson, P.C. \& Stidham, M.A. 1984. Imidatzolinones. Potent inhibitors of acetohydroxyacid synthase. Plant Physiology 76: 545-546.

Swanson, E.B., Coumans, M.P., Brown, G.L, Patel, J.D. \& Beversdorf, W.D. 1988. The characterization of herbicide tolerant plants in Brassica napus L. after in vitro selection of microspores and protoplasts. Plant Cell Reports 7: 83-87.

Swanson, E.B., Herrgesell, M.J., Arnoldo, M., Sippell, D.W. \& Wong, R.S.C. 1989. Microspore mutagenesis and selection: Canola plants with field tolerance to the imidazolinones. Theoretical and Applied Genetics 78: 525-530.

Tan, S., Evans, R.R., Dahmer, M.L., Singh, B.K. \& Shaner, D.L. 2005. Imidazolinone-tolerant crops: history, current status and future. Pest Management Science 61: 246-257.

Vilja-alan yhteistyöryhmä, VYR. 2008. Suomen vilja- ja öljykasviketjujen strategiaraportti 2008. Kansallisen viljastrategian seuranta. $117 \mathrm{~s}$. Verkkojulkaisu saatavilla:

http://www.vyr.fi/www/fi/liitetiedostot/ViljamarkkinaTR_pk/Suomen_vilja_ja_oljykasviketjujen_strategiaraport ti_2008.pdf 